Ahmad Riyansyah: Perbandingan Akuntansi Konvensional Dan Akuntansi Syariah |291

\title{
PERBANDINGAN AKUNTANSI KONVENSIONAL DAN AKUNTANSI SYARIAH MENURUT PEMIKIRAN SOFYAN SYAFRI HARAHAP
}

\author{
Ahmad Riyansyah \\ STAIN Mandailing Natal \\ ahmadriyansyah@stain-madina.ac.id
}

\begin{abstract}
The purpose of this study is to analyze the comparison of conventional accounting and Islamic accounting derived from the thoughts of Sofyan Syafri Harahap. Currently, the implementation of Islamic accounting is not widely practiced even neglected by companies due to the lack of introduction and concentration of Islamic accounting knowledge. This is because there are still few researchers who study and formulate the practice of Islamic accounting. The form of this research is qualitative through a descriptive approach. The method of the data collection is carried out through various sources including literature review of several related books, articles and related dissertations. Based on the analysis results, it is found that in comparison Sofyan Syafri Harahap argues that conventional accounting has many drawbacks. This is evident from the content of the verses in the Al-Qur'an and also the opinion of several previous Islamic scholars such as Lucas Pacioli. Islamic accounting must be able to guarantee that the information compiled or presented must be correct and free from elements of fraud or injustice, free from partiality to certain interests. The information provided must be transparent, tested, and can be accounted for in the afterlife. Knowledge of Islam is absolutely necessary to view accounting from an Islamic perspective.
\end{abstract}

Keywords:, accounting, Lucas Pacioli, Quran, sharia, Sofyan Syafri Harahap

\begin{abstract}
Abstrak
Tujuan dari penelitian ini untuk menganalisis perbandingan akuntansi konvensional dan akuntansi syariah dengan mendalami pemikiran Sofyan Syafri Harahap. Saat ini implentasi Akuntansi Syariah tidak banyak diamalkan bahkan diabaikan oleh perusahaan dikarenakan kurangnya keseriusan mengenal dan konsentrasi ilmu Akuntansi Syariah. Hal ini dikarenakan masih sedikit tokoh yang mengkaji hingga merumuskan praktik ilmu Akuntansi Syariah. Bentuk penelitian ini bersifat kualitatif melalui pendekatan yang deskriptif. Metode pengumpulan data penelitian dilakukan melalui berbagai sumber diantaranya kajian Pustaka dari beberapa buku terkait, artikel dan disertasi yang berkaitan. Berdasarkan hasil Analisa di dapati bahwa dalam perbandingannya Sofyan Syafri Harahap berpendapat bahwa akuntasi konvensional memiliki banyak kelelamahan. Hal ini terbukti dari kandungan ayat di AlQur'an dan juga pendapat beberapa ilmuwan-ilmuwan Islam terdahulu seperti halnya Lucas Pacioli. Akuntansi Islam harus bisa menjamin bahwa informasi yang disusun atau disajikan harus benar dan bebas dari unsur penipuan atau ketidakadilan, bebas dari pemihakan kepada kepentingan tertentu. Informasi yang diberikan harus transparan, teruji, dan dapat dipertanggungjawabkan dunia akhirat. Pengetahuan terhadap islam ini mutlak perlu untuk melihat akuntansi dalam perspektif Islam.
\end{abstract}

Kata Kunci: akuntansi, Lucas Pacioli, Qur'an, syariah, Sofyan Syafri Harahap 
292 AT-TAWASSUTH: Jurnal Ekonomi Islam, Volume V No. 2

Juli - Desember 2020: 291 - 314

\section{Pendahuluan}

Ilmu Akuntansi merupakan hal yang sangat penting untuk menunjang operasi perusahan. Akuntansi merupakan pencatatan operasional yang disusun secara teratur, rapi dan jelas. Apabila akuntansi dalam suatu perusahaan baik, maka perusahaan dapat dikatakan Profesional. Melalui Laporan Keuangan yang menampilkan produk akhir akuntansi untuk ditujukan kepada yang berkepentingan dan bermanfaat dalam mengambil keputusan. Akuntansi tepatnya akuntansi keuangan adalah alat komunikasi bisnis yang dapat memberikan informasi tentang kondisi keuangan (ekonomi) berupa posisi keuangan yang tertuang dalam jumlah kekayaan, utang dan modal suatu bisnis dan hasil usahanya pada suatu waktu atau periode tertentu. ${ }^{1}$

Di zaman yang penuh dengan pengaruh teknologi saat ini ilmu Akuntansi Syariah menjadi isu yang banyak menjadi perhatian penting bagi peneliti maupun praktisi. Sama halnya dengan sebuah pemikiran yang dihasilkan oleh Sofyan Syafri Harahap yang hingga sekarang belum ditemukan pendalaman analisis Akuntansi Syariah yang dihasilkan tokoh tersebut. Namun di berbagai sumber kita dapat temukan berbagai persepsi yang membahas implementasi Akuntansi Syariah. Melalui penelitian yang dilakukan oleh Kriyoto yang berjudul Keadilan dalam perspektif akuntansi islam telah menyinggung buah pikir mengenai Akuntansi Islam. Artikel ini bertujuan untuk menafsirkan sebuah kata yang terdapat pada Surat al-Baqarah ayat 282, yaitu kata "adil" (atau benar). Upaya penafsiran ini dilakukan dalam konteks akuntansi dengan tujuan untuk mencari bentuk akuntansi yang di dalamnya sarat dengan nilai-nilai keadilan. Nilai keadilan ini tidak saja merupakan nilai yang sangat penting dalam etika kehidupan sosial dan bisnis, tetapi juga merupakan nilai yang secara inheren melekat dalam fitrah manusia.

Akuntansi Syariah merupakan isu baru tetapi telah banyak menjadi perhatian penting bagi peneliti maupun praktisi. Sofyan Syafri Harahap adalah salah satu tokoh akuntansi yang memiliki perhatian terhadap akuntansi syariah. Sejak duduk di bangku Sekolah Menengah Ekonomi Pertama di Padangsidempuan, Sofyan Syafri Harahap mulai mengenal model perhitungan akuntansi dan lahir di tengah keluarga yang taat beragama juga membuatnya tertarik mendalami ilmu dan agamanya. 
Ahmad Riyansyah: Perbandingan Akuntansi Konvensional Dan Akuntansi Syariah |293

Ilmu akuntansi menentukan baik buruknya sebuah system pelaporan yang di adopsi oleh perusahaaan. Hal ini dikarenakan semua pencatatan keuangan disusun secara sistematis, dan teratur agar menciptakan sistem pelaporan yang bersifat professional. Disamping itu ilmu ini juga dapat dijadikan patokan untuk pengambillan keputusan yang tepat dalam sebuah perusahaan. Akuntansi tepatnya Akuntansi Keuangan atau ada juga yang menyebutnya akunting adalah bahasa atau alat komunikasi bisnis yang dapat memberikan informasi tentang kondisi keuangan (ekonomi) berupa posisi keuangan yang tertuang dalam jumlah kekayaan, utang dan modal suatu bisnis dan hasil usahanya pada suatu waktu atau periode tertentu. ${ }^{2}$

Seorang guru besar akuntansi berkebangsaan Amerika menulis sebagai berikut: "...the introduction of Arabic numerical greatly facilitated the growth of accounting" (Penemuan angka arab sangat membantu perkembangan akuntansi) kutipan ini menandai bahwa anggapan tadi dapat kita catat bahwa penggunaan angka Arab (1,2,3 dan seterusnya) mempunyai andil besar dalam perkembangan ilmu akuntansi. Artinya besar kemungkinan bahwa dalam peradaban Arab sudah ada metode pencatatan akuntansi. ${ }^{3}$

Menurut Sofyan Syafri sendiri, dalam Islam selalu ditekankan jangan melakukan kecurangan dan menimbulkan kerugian kepada pihak lain. Ketentuan ini harus ditegakkan dengan cara apa pun. Harus ada sistem yang dapat menjaga agar semua hak-hak stakeholders termasuk social dan pemerintah dijaga dan jangan sampai ada yang dirugikan dalam kontrak kerja sama apakah dalam bidang jual beli, mudharabah atau musyarakah. ${ }^{4}$

\section{Kajian Teori}

Di Indonesia Akuntansi Syariah berkembang dan berkelanjutan secara bertahap. Dalam hal ini beberapa ilmuwan, pakar atau pun peneliti Indonesia telah menulis dalam karyanya tentang Akuntansi Syariah ini. Seperti Sofyan Syafri Harahap dalam buku-bukunya Teori Akuntansi yang di dalamnya memuat Akuntansi Islam, Akuntansi Pengawasan dan Manajemen Dalam Perspektif Islam dan banyak karya Ekonomi Islam beliau yang lain telah menyinggung Akuntansi Syariah. Dalam 
pengertian atau buah pikir Sofyan Syafri Harahap tersebut, Akuntansi berjalan dalam segala aspek dan juga menuju tujuan Islam.

Buya Hamka dalam potongan tafsir Al-azhar juz 3 tentang surat al-Baqarah ayat 282 ini mengemukakan hal yang relevan dengan akuntansi sebagai berikut."....dan apabila dibelakang hari perlu dipersaksikan lagi sudah ada hitam di atas putih tempat berpegang dan keragu- raguan hilang, sebab sampai sekecilkecilnya pun dituliskan. "Dari ayat ini Sofyan Syafri Harahap mencatat bahwa dalam Islam, sejak munculnya peradaban Nabi Muhammad Saw. telah ada perintah untuk melakukan sistem pencatatan yang tekanannya adalah untuk tujuan kebenaran, kepastian, keterbukaan, keadilan antara dua pihak yang mempunyai hubungan muamalah. Dapat disimpulkan bahwa Islam mengharuskan pencatatan untuk tujuan keadilan dan kebenaran. ${ }^{5}$

Hendriksen, seorang guru besar akuntansi berkebangsaan Amerika menulis sebagai berikut: “...the introduction of Arabic numerical greatly facilitated the growth of accounting" (Penemuan angka arab sangat membantu perkembangan akuntansi) kutipan ini menandai bahwa anggapan tadi dapat kita catat bahwa penggunaan angka Arab (1,2,3 dan seterusnya) mempunyai andil besar dalam perkembangan ilmu akuntansi. Artinya besar kemungkinan bahwa dalam peradaban Arab sudah ada metode pencatatan akuntansi. ${ }^{6}$

Robert Arnold Russel, mengemukakan bahwa sebelum dikenal double entry oleh Pacioli sudah ada sistem double entry Arab yang lebih canggih yang merupakan dasar kemajuan bisnis di Eropa pada abad pertengahan. ${ }^{7}$ Ada beberapa tokoh lain yang mendukung pernyataan tersebut di antaranya Hamid, Russel Craig, dan Frank Clarke, T.E. Gambling dan R.A.A. Karim, Ahmed R. Belkaoui, Sabri dan Hisham, Muhammad Arkam Khan, Ali Shawki Ismail Shehata, D.R. Scott, dan Toshibaku Hayashi. ${ }^{8}$

Dari sudut lain Hiyashi juga menyinggung fungsi Tuhan sebagai "Akuntan". Tuhan melakukan pencatatan amal manusia di dunia dan akan dilaporkan nanti di hari akhirat di mana setiap orang akan mempertanggungjawabkan perbuatannya. Dan dari 
Ahmad Riyansyah: Perbandingan Akuntansi Konvensional Dan Akuntansi Syariah |295

rapor inilah nanti manusia ditentukan nasibnya apakah masuk azab (neraka) atau kenikmatan sorga Jannatun na' 'im. ${ }^{9}$

Dalam membahas zakat ia menyatakan bahwa dalam perhitungan zakat perlu prinsip Akutansi. Oleh karenanya ia mencoba memberikan saran bahwa menurut Akuntansi Islam maka metode penilaian yang tepat adalah Market Price bukan Historical Cost sebagaimana dalam Akuntansi Kapitalis. ${ }^{10}$

\section{Metode Penelitian}

Adapun metodologi yang penulis gunakan dalam penelitian ini adalah penelitian kualitatif. Jenis penelitian ini adalah penelitian kepustakaan (library research). Adapun yang dimaksud penelitian kepustakaan adalah suatu penelitian yang diadakan dengan cara mengumpulkan buku-buku serta sumber-sumber tertulis lainnya yang diperlukan dan mempelajarinya. Adapun pendekatan yang digunakan pada penelitian ini adalah pendekatan yuridis (perundang- undangan yang berlaku) dan normatif. Pendekatan ini dilakukan untuk mengungkap berbagai teori, pandangan hidup, pemikiran filsafat dan lain-lain dapat ditemui dalam berbagai peninggalan tertulis terutama dalam buku-buku yang dihasilkan pada zaman tertentu dalam prospek sejarah. Khususnya pada hasil penelitian tentang konsep akuntansi syariah. Sumber data yang digunakan dalam penelitian ini adalah data kepustakaan seperti buku (kitab), jurnal, majalah, dan data publikasi lainnya (sekunder) dari instansi yang terkait dengan penelitian.

\section{Hasil dan Pembahasan}

Dalam pemikiran seseorang terdapat beberapa factor yang dapat mempengaruhi diantaranya tempat lahir dan juga faktor lingkungan. Termasuk dalam kajian pemikiran seorang tokoh akuntansi yaitu Sofyan Syafri Harahap yang memiliki pengaruh terhadap hasil karya ilmiah yang beliau buat tentang Akuntansi Syariah. Prof. Sofyan Syafri Harahap, lahir di Tapanuli Selatan ${ }^{11}$, pada tanggal 23 November 1956 dan meninggal pada tanggal 2 Feburari 2012. Beliau menutup mata di usia 55 tahun. Almarhum Sofyan Syafri beralamat di jalan Tebet Timur Dalam I A No. 4, Jakarta Selatan memiliki Istri bernama Ny. Nirmawaty dan memiliki 5 (lima) orang anak. $^{12}$ 
Diantara akademisi yang banyak mengemukakan pentingnya nilai Islam dalam perekonomian adalah Sofyan Syafri Harahap. Diantara akademisi yang banyak mengemukakan pentingnya nilai islam dalam perekonomian adalah Sofyan Syafri Harahap. Dari 21 buku yang sudah ditulisnya, hampir seluruh memasukkan nilai-nilai Islam dan akuntansi. Beberapa harus menyorot soal akuntansi dan Islam, yakni Menuju Perumusan Teori Akuntansi Islam, Akuntansi Islam, Akuntansi, Manajemen dan Pengawasan dalam Perspektif Islam serta Unsur Agama dalam Sistem Pengawasan. ${ }^{13}$

Sofyan mengenal model perhitungan akuntansi sejak duduk di Sekolah Menengah Ekonomi Pertama di Padangsidempuan, Sumatera Utara. Dari situ ia melanjutkan studi ke Sekolah Menengah Ekonomi Tingkat Atas juga di Padangsidempuan dan kemudian menamatkan kuliahnya di Universitas Sumatera Utara. $^{14}$

Sofyan yang lahir dari keluarga yang taat menjalankan agama mengaku amat tertarik mendalami ilmu dan agamanya. Beliau berpendapat bahwa agama yang sesungguhnya sudah sempurna ini sudah tentu memiliki prinsip akuntansi sebagaimana berkembangnya di barat. Namun pemikiran yang awalnya sempat beliau yakini belum tertuang dalam textbook sebagaimana ilmu ekonomi barat. ${ }^{15}$

Sofyan belum menemukan rujukan, ia memulai dengan menulis artikel tentang Islam dan akuntansi serta akuntansi dan Islam. Kala itu ia masih mahasiswa di Universitas Sumatera Utara. Di tempat itu ia menggondol penghargaan mahasiswa teladan pada 1978. Menurut dia, ada kaitan erat antara akuntansi dan Islam terutama pada fungsi pengawasan. Dari situ, dia rajin menulis artikel yang temanya khusus berkaitan antara akuntansi dan nilai Islam. Sofyan melanjutkan S2 di Chicago AS. "Di negeri ini saya masih belum bisa menemukan rujukan tentang akuntansi Islam." Baru setelah di Australia, meneruskan pendidikan S3, ia mendapati buku-buku yang berkaitan dengan akuntansi Islam. ${ }^{16}$

Bersamaan dengan itu, adalah mulai runtuhnya perusahaan multinasional akibat skandal keuangan. Sementara lembaga swadaya masyarakat di dunia mulai kencang meneriakkan kerusakan lingkungan dan tatanan sosial akibat eksploitasi 
Ahmad Riyansyah: Perbandingan Akuntansi Konvensional Dan Akuntansi Syariah |297

perusahaan besar. Tahun 1999, gelar doktor diraihnya dari University of Adelaide Australia. Ia juga bergabung dengan Universitas Trisakti setelah pada tahun 1989 menjadi dosen teladan di Universitas Sumatera Utara. Sofyan mengaku makin rajin menggali literatur tentang akuntansi Islam setelah kembali dari Australia. Pada konferensi di Malaysia, ia bertemu dengan Hayashi yang disertasinya membuktikan bahwa sistem double entry dalam akuntansi Barat sesungguhnya berasal dariTimur Tengah karena sudah dipraktikkan di Timur Tengah pada abad 12-an. Sofyan juga mengungkapkan bahwa bukan Pachiolli yang pertama mengembangkan double entry sebagaimana ditulis di dunia barat. Disertasi Hayashi kemudian membawanya lebih dalam lagi pada akuntansi Islam. Pada saat yang sama, paradigma akuntansi juga makin berkembang. Ada yang mengembangkan akuntansi nilai, akuntansi lingkungan, akuntansi SDM, dan lainnya. ${ }^{17}$

Akuntansi tetap merupakan sebuah alat dalam bisnis. Melalui alat ini, diupayakan tercapai tujuan-tujuan tertentu dalam bisnis. Secara umum kita memahami bahwa akuntansi adalah salah satu alat bisnis bagi pihak-pihak tertentu. Secara umum kita memahami bahwa akuntansi adalah salah satu alat bisnis bagi pihak-pihak tertenntu. Alat ini diyakini perlu adanya untuk minimal dua tujuan utama, yakni:

1) Sebagai media pertanggung jawaban satu pihak terhadap pihak yang lain,

2) Sebagai alat bantu dalam mengambil keputusan bisnis.

Dua peran dasar ini, praktis tidak mengalami perubahan dalam akuntansi sejak zaman dahulu kala, walaupun sejumlah perubahan tertentu lainnya terjadi dalam dunia akuntansi. Dalam konteks tujuan pertama, walaupun tidak terlalu jelas, ada perubahan-perubahan yang intinya bergesernya orientasi pertanggung jawaban, yakni hanya terbatas hanya kepada pemilik modal saja/ stockholders .kalaupun kemudian muncul lagi perubahan yang memperluas area pertanggung jawaban kepada pihak yang lebih luas yakni stakeholders, namun dominasi kepentingan pemilik modal alias stockholders tetap terasa kental. Dan tujuan kedua, yakni akuntansi sebagai alat pengambil keputusan hingga menjadi bias. ${ }^{18}$ 
Apabila diperhatikan apa yang sedang terjadi dalam akuntansi konvensional maka amatlah jelas ketimpang besar terjadinya. Misalnya peran akuntansi yang sangat memihak kepada yang pemilik modal, atau pihak-pihak tertentudan cenderung mengabaikan aspek keadilan. Padahal Allah SWT telah mengingatkan bahwa "takarlah timbanganmu dengan benar" yang mengindikasikan perlunya ditegakkan konsep keadilan, termasuk dalam aspek informasi dan akuntansi. ${ }^{19}$

Bias-bias dalam bentuk seperti sering terjadi dalam akuntansi konvensional, bahkan dalam beberapa hal, sudah melebihi atau menabrak batas-batas moral dan mungkin hukum yang berlaku umum,seperti praktik window dressing, income smoothing dan semacamnya, dengan segala bentuk pola dan ragamnya. Situasi inilah yang merupakan salah satu penyebab kacaunya perekonomian sebuah bangsa. Mungkin krisis yang tak kunjung selesai yang sudah sekian tahun kita alami bersama, diantaranya juga karena faktor ini. ${ }^{20}$

Konsep dasar merupakan wujud atau kerangka dasar yang akan memengaruhi bentuk teori, cara memandang, dan cara mempraktikkan akuntansi dalam dunia ekonomi-bisnis. Serupa dengan hal ini, Kerlinger (1964) mendefinisikan teori akuntansi sebagai serangkaian membangun saling terkait, definisi, dan proposisi yang menyajikan pandangan sistematis fenomena dengan menentukan hubungan antar variabel dengan tujuan menjelaskan dan memprediksi fenomena. ${ }^{21}$

Hendriksen dan Van Breda mengatakan bahwa teori akuntansi adalah: Sebuah seperangkat hipotesis, konsep, prinsip-prinsip pragmatis yang membentuk kerangka umum referensi untuk menyelidiki sifat akuntansi. Lebih lanjut Hendriksen dan Van Breda mengatakan tujuan utama dari teori akuntansi adalah memberikan satu set prinsip yang diturunkan secara logis untuk dijadikan sebagai referensi dalam menilai dan mengembangkan praktik akuntansi. Pandangan Hendriksen dan Van Breda ini tidak jauh berbeda dengan pemikiran Iwan Triyuwono. Karena pandangan ini secara langsung menyatakan teori akuntansi memberikan pedoman bagi praktik akuntansi yang benar. Untuk itu penetapan kosep dasar Akuntansi Syariah didasarkan pada prinsip filosofis. Sedangkan prinsip filosofis itu sendiri secara implisit diturunkan 
Ahmad Riyansyah: Perbandingan Akuntansi Konvensional Dan Akuntansi Syariah |299

dari konsep faith, knowledge, dan action yang tidak lain adalah berasal dari nilai-nilai Tauhid. $^{22}$

Pola pikir oposisi biner ini merupakan suatu keadaan di mana posisi yang satu cendrung meniadakan atau memarjinalkan posisi yang lain, misalnya bentuk memarjinalkan substansi, atau kompetisi memarjinalkan kooperasi, dan lain-lain. Mengenai hal ini, Heines (1992) berpendapat bahwa akuntansi modern (sebagai produk dari budaya modernitas) cenderung memarjinalkan yang lain dari sebuah totalitas. Dan memang itulah budaya modernitas; ia sangat kental dengan nilai-nilai maskulin, dan sebaliknya memarjinalkan nilai-nilai feminin. Budaya ini jelas akan merusak peradaban manusia itu sendiri dan lingkungannya. ${ }^{23}$

Kearifan tradisi Islam telah mengajarkan asas "berpasangan" dalam takaran yang seimbang. Konsep ini sebenarnya sudah merupakan Sunnatullah. Namun budaya modernitas cenderung mengabaikan nilai-nilai feminin dari segala aspek kehidupan, demikian juga dalam dunia akuntansi seperti yang dikatakan oleh Heines, di mana Bahasa akuntansi adalah lengkungan-komunikator dan konstruktor sosial terhadapketidak seimbang kesadaran masyarakat, dan lingkungan ... yang sulit, kering, impersonal, objektif, jelas, luar fokus, orientasi-tindakan, analitik, holistik,

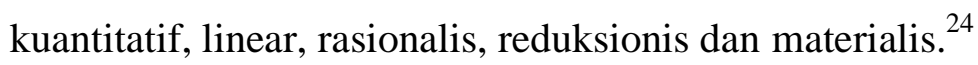

Dengan karakter semacam ini, akuntansi menjadi keras, impersonal, dan materialis. Karakter inilah yang dipancarkan oleh akuntansi modern melalui informasi akuntansi. Selanjutnya dalam masalah enterprise theory Harahap berpendapat bahwa teori tersebut lebih lengkap dibandingkan dengan teori yang lain, karena ia melingkupi aspek sosial dan pertanggungjawaban sebagaimana diungkapkan dalam pernyataan berikut:

Kalau ada pernyataan mengenai postulat, konsep, dan prinsip akuntansi Islam itu maka saat ini adalah masalah ini tidak semudah yang dibayangkan. Tentunya untuk merumuskan ini perlu pengkajian multi dimensi. yang jelas literatur saat ini belum bisa menjelaskannya. Tapi dari postulat, konsep, dan prinsip yang ada dapat kita saring mana yang sejalan dengan konsep Islam. Misalnya, konsep mana yang dipakai dari ketiga konsep: proproietary theory, entity theory, dan enterprise theory? 
300 |AT-TAWASSUTH: Jurnal Ekonomi Islam, Volume V No. 2

Juli - Desember 2020: 291 - 314

Maka jawabannya adalah enterprise theory karena lebih mencakup aspek sosial dan pertanggungjawaban Enterprise theory menjelaskan bahwa akuntansi harus melayani bukan saja pemilik perusahaan, tetapi juga masyarakat. ${ }^{25}$

Berdasarkan pendapatnya dapat penulis pahami bahwa Sofyan Syafri Harahap memiliki pemikiran yang sejalan dengan Iwan Triyuwono dalam hal konsep teoritis yang mampu memberikan dasar dalam pembentukan prinsip dan teknik akuntansi yang menghasilkan akuntabilitas dan informasi yang dibutuhkan, yaitu enterprise theory. Sofyan mengatakan akuntansi konvensional melahirkan ketidaksejajaran atau memiskinkan masyarakat karena hanya mementingkan pemilik modal. Sedangkan dalam Islam, syariat ditujukan untuk menyejahterakan umat secara umum. Dari situ kita ingin gambarkan bahwa laba bukan satu-satunya tujuan sebuah perusahaan tapi kesejahteraan. Ada hal lebih penting dari laba atau return on investment tapi juga return on social enterpreneurship atau fungsi perusahaan bagi masyarakat.

Islam memandang akuntansi tidak sekadar ilmu yang bebas nilai untuk melakukan pencatatan dan pelaporan saja, tetapi juga sebagai alat untuk menjalankan nilai-nilai islam (islamic values) sesuai ketentuan syariah. Ilmu penting ini ternyata dikembangkan oleh filosof islam yang terkenal yaitu Abu Yusuf bin Ishaq Al Khindi yang lahir tahun 801 M. Juga Al Karki dan Al Khawarizmi yang merupakan asal dari kata algorithm, algebra juga berasal dari kata arab yaitu "al jabr". Demikian juga sistem nomor desimal dan angka " 0 " yang kita pakai sekarang yang disebut angka arab sudah dikenal sejak 874 M, yang sudah diakui oleh Hendriksen merupakan sumbangan arab islam terhadap akuntansi. Ibnu khaldun lahir tahun $1332 \mathrm{M}$ adalah seorang filosof islam yang juga telah berbicara tentang politik, sosiologi, ekonomi, bisnis, perdagangan. Bahkan ada dugaan bahwa pemikiran mereka itulah sebenarnya yang dikemukakan oleh para filosof barat belakangan yang muncul pada abad ke -18 M. Sebenarnya sudah banyak pula ahli akuntan yang mengakui islam, misalnya RE Gambling, William Roget, Baydoun, Hayashi dari jepang dan lain lain. Seperti paciolli dalam memperkenalkan sistem double entry melalui ilmu matematika. Sistem akuntansi dibangun dari dasar kesamaan akuntansi. Aset $=$ Labilitas + Ekuitas $(\mathrm{A}=\mathrm{L}+\mathrm{E})$. Karena aljabar ditemukan pertama-tama oleh ilmuan muslim di zaman 
Ahmad Riyansyah: Perbandingan Akuntansi Konvensional Dan Akuntansi Syariah |301

keemasan islam, maka sangat logis jika ilmu akuntansi juga telah berkembang pesat di zaman itu, paling tidak menjadi dasar perkembangannya. ${ }^{26}$

Sofyan Syafri Harahap adalah salah satu tokoh akuntansi yang mengkritik akuntansi konvensional yang ramai dan berkembang pesat kajiannya dengan karyakarya akuntansinya yang terus dikembangkan di mulai dari Akuntansi, Manajemen dan Pengawasan dalam Perspektif Islam 1992, Teori Akuntansi 1993 dan edisi revisi 2008, Akuntansi Islam 1997 serta beberapa karyanya yang lain selalu membahas sistem pembukuan double entry telah ada sebelum Lucas Pacioli di Italia abad ke 13.

Sofyan Syafri Harahap mengemukakan teori akuntansi syariah, mengenai pemikiran akuntansi Vernon Kam dalam buku Accounting Theory menyatakan sebagai berikut Menurut sejarahnya, bahwa sistem pembukuan double entry muncul di Italia pada abad ke-13. Itulah catatan yang paling tua yang kita miliki mengenai sistem akuntansi double entry sejak abad ke-13 itu, namun adalah mungkin sistem double entry sudah ada sebelumnya. Kalimat terakhir ini artinya, ada kemungkinan akuntansi khususnya akuntansi Islam sudah ada sebelum Pacioli. Pendapat ini banyak didukung oleh berbagai penemuan dan konseptual sebagai berik ${ }^{27}$ :

Muhammad Khair, dalam menanggapi pendapat diatas menyatakan sepenuhnya setuju sikap itu. Namun, ia menyatakan sebagai berikut; Saya ingin membahas lebih lanjut pemahaman terhadap pertumbuhan double entry ini dari zaman dulu sampai zaman sekarang ini. ${ }^{28}$

Sebagian besar para akuntan dan para ekonom setuju bahwa factor utama sebagai penyebab perkembangan teknologi akuntansi adalah akibat pembentukan pertumbuhan perusahaan dalam lingkungan pasar yang demikian kompleks. Pertanyaan lainnya adalah apa kekuatan yang menimbulkan dan mendorong pembentukan dan pertumbuhan perusahaan, jawabnya adalah: Jiwa kapitalis, aspek sosial, tujuan akhir bukan laba, tetapi kepuasan masyarakat. Pendapat ini juga dapat menjadi dasar untuk menyatakan bahwa akuntansi sudah ada sebelum pascioli. ${ }^{29}$

Wujud Sistem ekonomi islam ini menjadi kegelsihaan Sofyan Syafri Harahap sejak lama. Beliau mengungkapkan bahwa ketika masih ngaji di Medan sudah mulai berpikir, bagaimanakah bentuk ekonomi Islam sebenarnya. Lalu setelah kuliah di 
302 AT-TAWASSUTH: Jurnal Ekonomi Islam, Volume V No. 2

Juli - Desember 2020: 291 - 314

USU Medan, ia masuk kuliah pada tahun 1975, ketika mempelajari tafsir al-Quran, ia terpukau pada Q.S. Al-Baqarah 282. Ayat yang berisi keharusan mencatat transaksi tidak tunai dianggapnya sebagai konsep Islam tentang akuntansi. Demikian terpukaunya pada ayat itu, sehingga ayat itupun ditulisnya di pembukaan skripsi. ${ }^{30}$

Dari situ Sofyan mulai mereka-reka bagaimana sebenarnya wujud akuntansi syariah. Hasil otak-atiknya itu ia tulis di sejumlah jurnal dan koran terbitan Medan di kala itu. Di antaranya ia menulis di sebuah koran Medan, dengan judul, "Akuntansi dalam Islam dan Islam dalam akuntansi”. Boleh jadi pemikirannya tergolong melangkah jauh ke depan, karena ketika itu suara-suara tentang perbankan syariah dan ekonomi syariah belum terdengar. Bukan hanya itu, di Medan ia juga mendirikan Forum Kajian Ekonomi dan Perbankan Islam. Karena aktivitasnya itulah, ketika Bank Muamalat Indonesia berdiri pada tahun 1992, Sofyan direkrut oleh Zainul Bahar Noor untuk bergabung di Bank Syariah pertama itu. ${ }^{31}$

Buah pikir, karya-karya atau pemikiran Prof. Sofyan telah banyak dituangkan dalam bukunya yang luar biasa terutama dalam mengupas Akuntansi Syariah. Salah Satu contoh buku karya beliau adalah Akuntansi Islam. Tentu saja dengan menghasilkan karya tersebut dapat membuat efek positif keilmuan terhadap orangorang yang membaca, meneliti dan mempelajari karya-karyanya. Dengan banyak karya yang beliau hasilkan membuat orang-orang yang memerlukan atau melakukan kajian Ekonomi terkhusus Akuntansi apalagi dalam hal Akuntansi Syariah akan mencari tahu dan akan mengenal sosok beliau.

Analisis lebih lanjut pemikiran Sofyan Syafri Harahap tentang Akuntansi Syariah, argumentasi dan kritik terhadap Akuntansi Konvensional mendapati bahwa saat ini perkembangan yang terjadi di masyarakat tampaknya mengarah kepada asalnya "back to nature" atau "back to basic" katanya. Naisbitt menerjemahkan fenomena ini dalam buku Megatrend 2000 yang dituliskannya berdasarkan hasil penelitian dengan memakai teori kecenderungan statistik, menyebutkan bahwa masyarakat di tahun 2000 dan seterusnya semakin mengalami peningkatan "religiousity", semangat keagamaan. Artinya masyarakat akan kembali memberikan perhatian kepada ajaran agamanya. ${ }^{32}$ 
Ahmad Riyansyah: Perbandingan Akuntansi Konvensional Dan Akuntansi Syariah |303

Dalam berbagai tulisan mengenai tanggapan atau persisnya kritik terhadap akuntansi sekarang tampak ketidakpuasan terhadap apa sesungguhnya yang diberikan akuntansi konvensional pada masyarakat. Kalau akuntansi berfungsi sebagai sumber informasi dalam proses pengambilan keputusan maka ditemukan tiga hal. Pertama, kompleksitas proses pengambilan keputusan dalam bisnis saat ini tidak bisa hanya mengandalkan informasi akuntansi. Kedua, kika selama ini sumber informasi akuntansi dinilai dominan maka ternyata situasi ekonomi maupun bisnis justru masih mengalami berbagai kerugian, korupsi, kecurangan, crash, depresi, dan sebagainya. Artinya informasi akuntansi yang selama ini dianggap sebagai dasar pengambilan keputusan ternyata banyak keputusan yang diambil dari sumber itu tidak menghasilkan output yang baikk bahkan yang terjadi depresi, bangkrut, ekonomi yang lesu dan sebagainya. Ketiga, unsur etika semakin longgar. Karena informasi akuntansi dianggap bebas nilai maka akuntansi dibawa oleh pihak yang berkepentingan untuk vestednya sehingga bisa merugikan masyarakat. ${ }^{33}$

Oleh karena pengalaman ini, maka muncul pemikiran baru bahwa akuntansi harus merubah diri atau "intropeksi" jika seandainya ia tidak mau ditinggalkan pemakaiannya atau dimasukkan dalam museum peradaban. Salah satu pemikiran itu adalah perlunya akuntansi menggeser fungsinya dari "decision making facilitating function" ke arah lain yang lebih bermanfaat. Dari sini maka muncul fungsi "accountability" yang sebenarnya telah ada sejak kelahiran. Lee yang menganjurkan itu dalam makalahnya pada seminar internasional yang membahas isu tersebut menyatakan bahwa akuntansi konvensional harus disempurnakan dengan menambah media:

1) Penilaian terhadap efisiensi manajemen.

2) Pengungkapan terhadap kecurangan manajemen.

3) Penjelasan mengenai budget atau rencana kerja.

Akuntansi harus semakin menghilangkan unsur alokasi, akuntansi harus lebih scientific. Akuntansi harus menyajikan informasi yang relevan, tidak hanya informasi kuantitatif tetapi juga kualitatif. ${ }^{34}$ 
Kecendrungan ini ternyata telah diseminarkan di Konferensi Internasional Akuntansi di Adelaide Australia 1994 yang baru lalu. Kecenderungan ini ternyata kalau dikaji dengan pernyataan yang sudah popular diatas "back to nature" atau "back to basic". Awal sejarahnya akuntansi muncul untuk pertanggungjawaban sebagaimana jiwa ayat al-Qur'an surat al- Baqarah 282 dan sejarah awal munculnya profesi auditing. Semakin berkembangnya praktik ekonomi di mana produksi bukan lagi hanya untuk konsumsi sendiri atau konsumsi lokal maka muncullah praktek perdagangan. Muncullah perkembangan alat tukar dari metode barter sebelumnya. Dari situ muncullah perbedaan waktu dan tempat transaksi yang memerlukan catatan atau media catatan baik bentuk batu, coin, kayu, tanah liat, dan bentuk lainnya. Itulah yang ditemukan dari berbagai penemuan arkeologi di Mesir Kuno, Romawi, Cina, juga di Eropa. Kemudian bisnis semakin luas, praktek agen semakin banyak sehingga pemilik tidak bisa langsung lagi mengawasi bisnisnya maka dalam proses pembagian laba misalnya mereka memerlukan pihak lain yang independen yang dapat memberikan kesaksian terhadap perhitungan si agen tadi. Inilah embrio auditor. ${ }^{35}$

Akuntansi sebenarnya merupakan domain muamalah dalam kajian Islam. Artinya diserahkan pada kemampuan akal pikiran manusia untuk mengembangkannya. Namun, karena pentingya permasalahan ini maka Allah SWT. Bahkan memberikannya tempat dalam kitab suci Alqur'an surat Al-Baqarah Ayat 282.

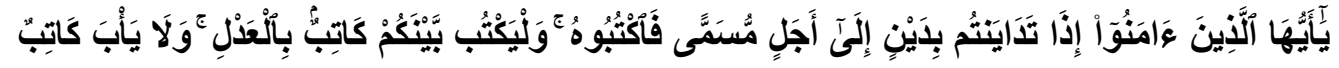

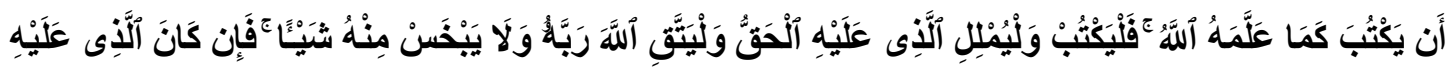

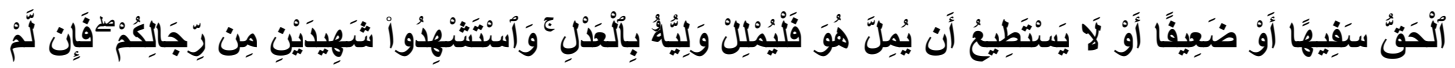

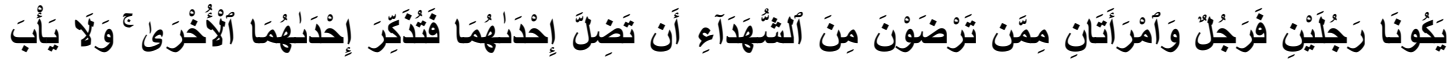

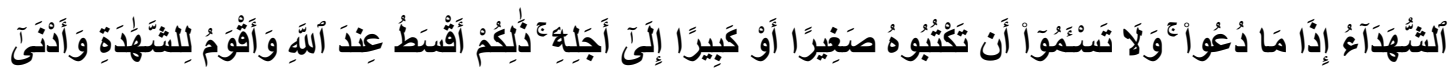

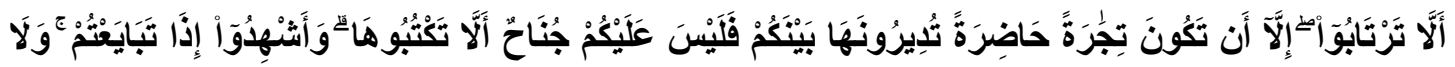

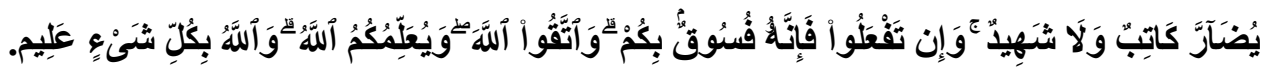

Artinya: Hai orang-orang yang beriman, apabila kamu bermuamalah tidak secara tunai untuk waktu yang ditentukan, hendaklah kamu menuliskannya. Dan hendaklah seorang penulis di antara kamu menuliskannya dengan benar. Dan 
Ahmad Riyansyah: Perbandingan Akuntansi Konvensional Dan Akuntansi Syariah |305

janganlah penulis enggan menuliskannya sebagaimana Allah mengajarkannya, meka hendaklah ia menulis, dan hendaklah orang yang berhutang itu mengimlakkan (apa yang akan ditulis itu), dan hendaklah ia bertakwa kepada Allah Tuhannya, dan janganlah ia mengurangi sedikitpun daripada hutangnya. Jika yang berhutang itu orang yang lemah akalnya atau lemah (keadaannya) atau dia sendiri tidak mampu mengimlakkan, maka hendaklah walinya mengimlakkan dengan jujur.Dan persaksikanlah dengan dua orang saksi dari orang-orang lelaki (di antaramu). Jika tak ada dua oang lelaki, maka (boleh) seorang lelaki dan dua orang perempuan dari saksisaksi yang kamu ridhai, supaya jika seorang lupa maka yang seorang mengingatkannya.Janganlah saksi-saksi itu enggan (memberi keterangan) apabila mereka dipanggil; dan janganlah kamu jemu menulis hutang itu, baik kecil maupun besar sampai batas waktu membayarnya. Yang demikian itu, lebih adil di sisi Allah dan lebih menguatkan persaksian dan lebih dekat kepada tidak (menimbulkan) keraguanmu. (Tulislah mu'amalahmu itu), kecuali jika muamalah itu perdagangan tunai yang kamu jalankan di antara kamu, maka tidak ada dosa bagi kamu, (jika) kamu tidak menulisnya. Dan persaksikanlah apabila kamu berjual beli, dan janganlah penulis dan saksi saling sulit menyulitkan. Jika kamu lakukan (yang demikian), maka sesungguhnya hal itu adalah suatu kefasikan pada dirimu. Dan bertakwalah kepada Allah; Allah mengajarmu; dan Allah Maha Mengetahui segala sesuatu.”36

Melalui ayat Al-Qur'an diatas kita dapat melihat pengertian akuntansi yaitu hisab, hasibah, muhasabah, dan hisaban. Muhasabah secara bahasa berarti menimbang atau memperhitungkan. Cikal bakal akuntansi tidak dipungkiri adalah ilmu hisab yaitu dewasa ini ilmu Matematika yang lumrah menjadi ilmu dasar dalam mata pelajaran sekolah. Sebenarnya kata hisab tidak hanya ditemukan di dalam alQuran. Beberapa hadis Nabi yang menggunakan kata hisab adalah, Sabda Nabi SAW yang menyatakan, "yang pertama di hisab di hari kiamat nanti ialah salat; maka jika salat itu dikerjakan dengan benar, benarlah semua perbuatannya, tetapi jika sholat itu rusak, rusaklah semua perbuatannya. (HR. Thabrani). Makna hisab pada hadis ini adalah menghitung atau mengevaluasi. ${ }^{37}$

Kalau kita dapat memahami surat Al-Baqarah ayat 282, Allah memerintahkan untuk melakukan penulisan secara benar atas segala transaksi yang pernah dilakukan 
306 |AT-TAWASSUTH: Jurnal Ekonomi Islam, Volume V No. 2

Juli - Desember 2020: 291 - 314

selama melakukan muamalah. Dan hasilnya dapat digunakan sebagai informasi untuk menentukan apa yang akan diperbuat oleh seseorang. ${ }^{38}$

Surah di atas memberi perintah kepada orang-orang yang beriman agar melakukan pencatatan transaksi muamalah-nya yang tidak tunai antar manusia seperti: hutang-piutang, jual beli dan sejenisnya. Pencatatan harus dilakukan oleh juru tulis yang jujur dan adil. Juru tulis yang jujur dan adil di dalam ayat ini adalah isyarat diperlukannya profesi akuntan.

Penempatan ayat ini juga unik dan relevan dengan sifat akuntansi itu. Ia ditempatkan dalam surat ke-2 yang dapat dianalogikan dengan double entry, ditempatkan di ayat 282 yang menggambarkan angka keseimbangan atau Neraca. Bahkan juga bisa dikaji relevansi ayat berikut dalam konteks double entry atau sifat berpasangannya. Pada surat al-Zariyat ayat 49: "Dan segala sesuatu kami ciptakan berpasang-pasangan supaya kamu mengingat kebesaran Allah." Dan juga surat Yasin ayat 36:"Maha Suci Tuhan yang telah menciptakan pasangan-pasangan semuanya, baik dari apa yang ditumbuhkan oleh bumi dan dari diri mereka maupun dari apa yang tidak mereka ketahui., 39

Jika dikaji sistem jagad dan manajemen alam ini ternyata peran atau fungsi akuntansi sangat besar. Allah memiliki akuntansi malaikat yang sangat canggih, yaitu Rakid dan Atid, malaikat yang menuliskan/menjurnal transaksi yang dilakukan manusia, yang menghasilkan buku/neraca yang nanti akan dilaporkan kepada kita (owner) di akhirat. Dipertegas dalam surat al-Infithar (82) ayat 10-12, "Padahal sesungguhnya pada kamu ada malaikat yang memonitor pekerjaanmu (10).Yang mulia di sisi Allah dan yang mencatat pekerjaanmu itu (11). Mereka mengetahui apa yang kamu kerjakan (12)."40

Bidang akuntansi melahirkan profesi akuntan. Profesi ini lahir karena anggapan bahwa penyaji laporan keuangan, yaitu manajemen dianggap tidak akan dapat berlaku adil dan objektif dalam melaporkan hasil prestasinya. Oleh karena itu, diperlukan pihak penyaksi independen yang menilai seberapa jauh laporan yang disusun manajemen sesuai dengan standar akuntansi keuangan yang ada. 
Ahmad Riyansyah: Perbandingan Akuntansi Konvensional Dan Akuntansi Syariah |307

Dalam konteks inilah maka Al-Quran Surat An-Nisa' ayat 135 memberikan pedoman Sofyan Syafri Harahap mengungkapkan, akuntansi konvensional memiliki problematika sehingga muncul pemikiran dan gagasan untuk menegakkan akuntansi islam/syariah. Sofyan Syafri Harahap menuliskan, dalam permulaan sejarahnya sampai ke abad XX, laporan keuangan masih dikatakan benar atau true. Namun akhirnya, laporan keuangan tidak dikatakan benar lagi, tetapi dipakai istilah wajar, layak atau fairly stated. Keadaan ini menunjukkan bahwa akuntansi konvensional dengan berbagai instrument dan sifat-sifatnya merasa tidak bisa menjamin kebenaran output akuntansi itu kepada para akuntan publik sebagai pelaku attest function sebagai berikut.

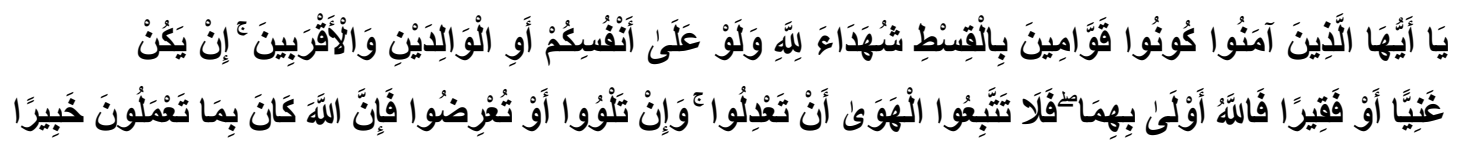

Wahai orang-orang yang beriman jadilah kamu orang yang benar- benar penegak keadilan, menjadi saksi karena Allah biarpun terhadap dirimu sendiri, ibulbapakmu, kaum kerabatmu. Jika ia kaya ataupun miskin, Allah lebih tahu kemashlahatannya. Maka, janganlah kamu mengikuti hawa nafsu karena ingin menyimpang dari kebenaram, dan jika kamu memutarbalikkan kata-kata atau enggan menjadi saksi, sesungguhnya Allah adalah Maha Mengetahui segala apa yang kamu kerjakan. ${ }^{41}$ Ayat ini jelas menerangkan kualitas penyaksian yang diinginkan yaitu independen dan objektif. ${ }^{42}$ Untuk menunjang independen dan objektifnya kualitas penyaksian maka perlu adanya prinsip akuntansi dalam etika islam; prinsip akuntansi yang diterima umum harus ditaat sepanjang tidak bertentangan dengan hukum Islam. Akuntansi sosial adalah prinsip akuntan dan transaksi, yang penting transaksi yang tidak sesuai dengan hukum Islam harus dihindarkan. ${ }^{43}$

Islam membenarkan setiap kegiatan bisnis termasuk akuntansi selama tidak menyakiti atau melakukan kecurangan dalam hubungan muamalah. Dalam aktivitas akuntansi yang diinginkan islam harus ideal dengan syariat Islam, akuntansi dalam Islam sangat mementingkan tingkah laku sebagai unsur yang juga berperan dalam kesatuan ekonomi. $^{44}$ 
308 AT-TAWASSUTH: Jurnal Ekonomi Islam, Volume V No. 2

Juli - Desember 2020: 291 - 314

Akuntan adalah pihak aktor yang berperan terhadap pembentukan dan pelaksanaan akuntansi sebagai struktur. Realitas akuntansi merupakan bagian dari bagaimana akuntan mengambil peran. Akuntan pada dasarnya sebagaimana manusia adalah makhluk yang memiliki fitrah kebaikan, kejujuran, kepedulian, cinta dan keadilan, tetapi aktualitas fitrah tersebut diproduksi oleh realitas struktur. Dalam hal ini akuntan yang berwatak kapitalislah yang menggiring akuntan untuk berperawakan kapitalis pula. $^{45}$

Sebagai gambaran Business Week (January 28,2002) memberikan beberapa tindakan reformasi Profesi Akuntan sebagai berikut:

1) Terapkan dan mantapkan pelaksanaan "self regulation" secara lebih tegas.

2) Hentikan pemberian jasa konsultan untuk langganan yang menerima jasa audit.

3) Lakukan rotasi auditor.

4) Terapkan lebih banyak "audit forensic.

5) Batasi infiltrasi auditor ke perusahaan.

6) Reformasi komite audit

7) Bersihkan aturan atau standar akuntansi dari hal hal yang memungkinkan dapat menimbulkan ·Creative accounting”.

Beberapa ide ini sudah lama menjadi bahan diskusi di Tanah Air dan bahkan secara teoritis sudah dijadikan sebagai kebijakan namun belum bisa secara efektif diterapkan di lapangan. Sebaiknya kasus Enron Corporation di Amerika dapat menjadi pelajaran berharga bagi pejabat yang berwenang di organisasi profesi IAI kita tercinta. Marilah sama-sama kita tingkatkan perhatian dan upaya profesi akuntan untuk menjaga kredibilitas, amanah, integritas dengan mematuhi semua standar dan kode etik yang ada dan menjunjung tinggi etika dan moralitas agar profesi kita tetap mendapat tempat di hati masyarakat. Kalau ini bisa kita jaga, maka peristiwa seperti yang menimpa akuntan dalam kasus Enron maupun kasus-kasus lain di Indonesia dapat kita hilangkan. 
Ahmad Riyansyah: Perbandingan Akuntansi Konvensional Dan Akuntansi Syariah |309

Selaras dengan pernyataan di atas, menurut Islam akuntan harus memenuhi persyaratan sebagai berikut:

1) Akuntan harus mengetahui dan meyakini Islam sebagai cara hidupnya.

2) Akuntan harus memiliki karakter yang baik, jujur dan terpercaya.

3) Akuntan harus adil, efisien, dan independen.

4) Akuntan harus bertanggung jawab kepada masyarakat dan Negara.

5) Akuntan harus bertanggung jawab untuk melaporkan setiap transaksi yang bertentangan dengan hukum Islam. ${ }^{46}$

Dalam sudut pandang lain oleh Sofyan Syafri Harahap dalam karyanya yang sama Teori Akuntansi mengungkapkan bahwa kendatipun secara de facto kita sudah melihat entitas bisnis syariah telah berdiri dan telah menggunakan akuntansi syariah, masih ada anggapan bahwa tidak ada akuntansi Syariah Islam itu. Mereka menilai kalaupun ada, sama saja dengan akuntansi konvensional atau akuntansi kapitalis yang kita kenal. Kalaupun berbeda, hanya dalam tingkat istilah ataupun dalam hal penekanan dalam etikanya. Oleh karena itu, kita tidak perlu repot cukup mengisi akuntansi kapitalis itu dengan nilai-nilai Islam. ${ }^{47}$

Pengetahuan terhadap Islam ini mutlak perlu untuk melihat akuntansi dalam perspektif Islam. Pentingnya pencatatan, keterangan maupun keadilan yang telah Islam tegaskan dalam Qur'an Surat Al-Baqarah 282 mengharuskan setiap kita untuk mencatat segala aktifitas transaksi, melakukan pembukuan, dan tidak melakukan kecurangan. Kapitalis mengklaim bahwa Akuntansi dilahirkan oleh Lucas Pacioli namun jelas melalui sejarahnya Islam lebih dulu menurunkan ayat Qur'an yang kita singgung tadi. Kendatipun demikian akuntansi kapitalis atau yang kita kenal dengan akuntansi konvensional banyak memeliki kelemahan. ${ }^{48}$

Sejalan dengan hal tersebut, pemikir akuntansi islam Iwan Triyuwono juga menegaskan bahwa pengetahuan (teori) akuntansi dikonstruksikan melalui bimbingan syariah. Oleh karena itu menurut etika syariah, syariah harus didasarkan pada konsep komplemen dua hal atau lebih. ${ }^{49}$ 
310 AT-TAWASSUTH: Jurnal Ekonomi Islam, Volume V No. 2

Juli - Desember 2020: 291 - 314

Akuntansi syariah adalah produk dari sistem bisnis syariah Islam. Sistem bisnis syariah Islam dibangun berdasar pada landasan spiritual Iman, dan amal. Iman adalah keyakinan kepada Tuhan Pencipta alam dan seisinya. Hanya Tuhan yang kekal, yang lainnya seperti alam, manusia dan sosial adalah fana, berubah dan berkembang, termasuk praktek dan teori akuntansi. Sistem akuntansi syariah dibangun berdasarkan pada landasan materiil sistem ekonomi islam dan landasan spiritual Al-Qur'an. ${ }^{50}$

Penemuan metode baru dalam akuntansi selalu mengalami penyesuaian dengan kondisi tertentu sehingga dalam perkembangan selanjutnya ilmu akuntansi lebih cenderung dengan ilmu sosial. Islam juga memandang akuntansi tidak hanya sekedar ilmu yang bebas menilai untuk melakukan pencatatan dan pelaporan saja, akan tetapi sebagai alat untuk menjalankan nilai-nilai islam sesuai ketentuan syariah. Negara madinah merupakan letak awal perkembangan islam yaitu pada tahun $622 \mathrm{~m}$ atau tahun $1 \mathrm{H}$. Hal ini didasari oleh konsep bahwa seluruh muslim adalah bersaudara tanpa memandang ras, suku, warna kulit, dan golongan lainnya, sehingga kegiatan kenegaraan dilakukan secara gotong royong atau kerja sama karnanya Negara tersebut tidak memiliki pemasukan dan pengeluaran. ${ }^{51}$

Problem Akuntansi Konvensional banyak terjadi kelemahan dari akuntansi itu sendiri karena akuntansi yang digambarkan tidak menegaskan perintah Tuhan dan terkesan ragu-ragu serta berubah-ubah, kita ambil contoh dahulunya disahkan dengan true sekarang berubah menjadi wajar. Oleh karena beberapa kendala tersebut, maka bagi penulis melalui pemikiran Sofyan Syafri Harahap yang mengikuti landasan AlQur'an, Akuntansi Syariah memiliki Urgensi dalam Praktik Akuntansi Dunia.52

\section{Kesimpulan}

Sofyan Syafri Harahap mengemukakan bahwa dalam permulaan sejarahnya sampai ke abad XX, laporan keuangan masih dikatakan benar. Namun akhirnya, laporan keuangan tidak dikatakan benar lagi, tetapi dipakai istilah wajar, layak atau fairly stated. Keadaan ini menunjukkan bahwa akuntansi konvensional dengan berbagai instrument dan sifat-sifatnya merasa tidak bisa menjamin "kebenaran" output akuntansi tersebut. Kapitalis mengklaim bahwa akuntansi dilahirkan oleh 
Ahmad Riyansyah: Perbandingan Akuntansi Konvensional Dan Akuntansi Syariah |311

Lucas Pacioli namun jelas melalui sejarahnya Islam lebih dulu menurunkan ayat alQuran. Akuntansi Islam harus bisa menjamin bahwa informasi yang disusun atau disajikan harus benar dan bebas dari unsur penipuan atau ketidakadilan, bebas dari pemihakan kepada kepentingan tertentu. Informasi yang diberikan harus transparan, teruji, dan dapat dipertanggungjawabkan dunia akhirat. Pengetahuan terhadap islam ini mutlak perlu untuk melihat akuntansi dalam perspektif Islam.

\section{Endnote}

${ }^{1}$ Sofyan Syafri Harahap, Teori Akuntansi (Jakarta: RajaGrafindo Persada 1993) h. 4

2 Ibid

${ }^{3}$ Ibid., h. 362 .

${ }^{4}$ Ibid., h. 351.

${ }^{5}$ Ibid., h. 352.

${ }^{6}$ Sofyan Syafri Harahap, Teori Akuntansi (Jakarta: RajaGrafindo Persada 1993) h.362

${ }^{7}$ Sofyan Syafri Harahap, Akuntansi Islam (Jakarta: Bumi Aksara 1997) h. 9

${ }^{8}$ Ibid. h. 9

${ }^{9}$ Ibid. h. 9

${ }^{10}$ Ibid. h. 9

11 Lihat Riwayat hidup Sofyan Syafri Harahap pada karyanya Akuntansi Pengawasan dan Manajemen Dalam PerspektifIslam(FakultasEkonomi Universitas TrisaktiJakarta, 1992)

12 Sofyan Syafri Harahap, Krisis Akuntansi Kapitalis dan Peluang Akuntansi Syariah (Jakarta: Pustaka Quantum 2007) h. 141.

${ }^{13}$ Ibid., h. 142.

14 Sofyan Syafri Harahap, Krisis Akuntansi Kapitalis dan Peluang Akuntansi Syariah (Jakarta: Pustaka Quantum 2007) h. 143.

${ }^{15}$ Ibid

16 Ibid

${ }^{17}$ Ibid

18 Akhyar Adnan, Akuntansi Syariah: Arah, Prospek dan Tantangannya, (Yogyakarta: UII Press 2005) h. 78-79

${ }^{19}$ Ibid

${ }^{20}$ Ibid

21 F.N Kerlinger, Foundation of Behavioral Research, (New York: Holt, Rinehart and Winston), h. 11.
} 
312 AT-TAWASSUTH: Jurnal Ekonomi Islam, Volume V No. 2

Juli - Desember 2020: 291 - 314

${ }^{22}$ Eldon S Hendriksen dan Michael F van Breda, accounting Theory, (Chicago: Irwin, 1992), h.

21.

${ }^{23}$ D. Ruth Heines, Accounting Filling The Negative Space, Accounting Organization, and Society, (1992), Vol. 17. No. 3/4, h. 328.

${ }^{24}$ Ibid

${ }^{25}$ Sofyan Syafri Harahap, Akuntansi Islam, (Jakarta: Bumi Aksara, 1996), h. 154-155.

${ }^{26}$ Sri Nurhayati Wasilah, Akuntansi Syariah, ed. 2, (Jakarta : Salemba Empat, 2011), h. 50 - 51

${ }^{27}$ Sofyan Syafri Harahap, Teori Akuntansi (Jakarta: RajaGrafindo Persada 1993), h.362

${ }^{28}$ Ibid. h.362

${ }^{29}$ Ibid. h.362

${ }^{30}$ Sofyan Syafri Harahap, Akuntansi Islam (Jakarta: Bumi Aksara 1997) h. 1.

${ }^{31}$ Ibid., h. 1.

${ }^{32}$ Ibid., h. 3.

${ }^{33}$ Ibid., h. 4.

${ }^{34}$ Ibid., h. 4.

${ }^{35}$ Sofyan Syafri Harahap, Akuntansi Pengawasan dan Manajemen Dalam Perspektif Islam (Jakarta: Universitas Trisakti Jakarta 1992) h. 4

${ }^{36}$ Kementrian Agama RI, Alquran dan Terjemahan (Bandung: Wali, 2012).

${ }^{37}$ Azhari Akmal Tarigan, Tafsir Ayat-Ayat Ekonomi al-Qur'an (Bandung: Cipta Pustaka 2014), h. 240.

${ }^{38}$ Saparuddin Siregar,Akuntansi Zakat dan Infak/ Sedekah Sesuai PSAK dan LAZ (Medan: Wal Ashri Publishing 2013) h. 2.

${ }^{39}$ Kementrian Agama RI, Alquran dan Terjemahan (Bandung: Wali, 2012).

${ }^{40}$ Ibid.

${ }^{41}$ Ibid

${ }^{42}$ Sofyan Syafri Harahap, Akuntansi Islam (Jakarta: Bumi Aksara 1997) h. 239

${ }^{43}$ Ibid

${ }^{44}$ Husain Syatah, an-Nawhi as-Sulukiah li Ma'ayir al-Ada-I wa Takhtith al-Intaj fi Dhaui alFikri al-Islami. (Mesir: Muktamar Ilmi ke 7: 1980) cet. Lembaga Ilmiah Untuk Manajamen Keuangan

${ }^{45}$ Alimuddin, Muhammad Ruslan, Ideologi Akuntansi Islam (Jakarta: Rajawali Pers 2016) h. 167

${ }^{46}$ Husain Shahata, Accounting an Islam, Journal of Islamic Economy, (Februari 1982)

${ }^{47}$ Ahmad Riyansyah. 2017. Pemikiran Sofyan Syafri Harahap dan Penerapannya. At-Tafahum: Journal of Islamic Law 1

${ }^{48}$ Ibid

${ }^{49}$ Iwan Triyuwono.Organisasi dan Akuntansi Syariah (Yogyakarta: LKiS 2000) h. 324

${ }^{50}$ Iwan Triyuwono, dkk., Filsafat Ilmu Akuntansi. (Jakarta: Mitra Wacana Media 2016) h. 112 
Ahmad Riyansyah: Perbandingan Akuntansi Konvensional Dan Akuntansi Syariah |313

${ }^{51}$ Dawam Rahardjo, Sejarah Pemikiran Ekonomi Islam, cet. 2, (Jakarta: Wisma Nugrasatana, 2002), h. 61.

\section{Daftar Pustaka}

Adnan, Akhyar. 2005. Akuntansi Syariah: Arah, Prospek dan Tantangannya, Yogyakarta: UII Press.

Alimuddin, Muhammad Ruslan. 2016. Ideologi Akuntansi Islam. Jakarta: Rajawali Pers.

Harahap, Sofyan Syafri. Akuntansi Pengawasan dan Manajemen Dalam Perspektif Islam . 1997. Akuntansi Islam. Jakarta: Bumi Aksara. . 2007. Krisis Akuntansi Kapitalis dan Peluang Akuntansi Syariah. Jakarta: Pustaka Quantum. 1993. Teori Akuntansi. Jakarta: RajaGrafindo Persada.

Heines, D. R. 1992. Accounting Filling The Negative Space. Accounting Organization, and Society, 17(3/4).

Hendriksen, Eldon S dan Michael F van Breda. 1992. Accounting Theory. Chicago: Irwin.

Kementrian Agama RI. 2012. Alquran dan Terjemahan, Bandung: Wali.

Kerlinger, F.N. Foundation of Behavioral Research. New York: Holt, Rinehart and Winston.

Rahardjo, Dawam. 2002. Sejarah Pemikiran Ekonomi Islam, cet. 2. Jakarta: Wisma Nugrasatana.

Riyansyah, Ahmad. 2017. Pemikiran Sofyan Syafri Harahap dan Penerapannya. AtTafahum: Journal of Islamic Law 1.

Shahata, Husain. 1982. Accounting an Islam. Journal of Islamic Economy. 
314 AT-TAWASSUTH: Jurnal Ekonomi Islam, Volume V No. 2

Juli - Desember 2020: 291 - 314

Siregar, Saparuddin. 2013. Akuntansi Zakat dan Infak/Sedekah Sesuai PSAK dan LAZ Medan: Wal Ashri Publishing.

Syatah, Husain. 1980. an-Nawhi as-Sulukiah li Ma'ayir al-Ada-I wa Takhtith al-Intaj fi Dhaui al-Fikri al-Islami. Cet. 7 Lembaga Ilmiah Untuk Manajamen Keuangan. Mesir: Muktamar Ilmi.

Tarigan, Azhari Akmal. 2012. Tafsir Ayat-Ayat Ekonomi Al-Qur'an. Bandung: Cipta Pustaka Media Perintis.

Triyuwono, Iwan dan Mohammad As'udi. 2001. Akuntansi Syari'ah: Memformulasikan Konteks Laba dalam Memetafora Zakat. Jakarta: Penerbit Salemba Empat.

Triyuwono, Iwan. dkk. 2016. Filsafat Ilmu Akuntansi. Jakarta: Mitra Wacana Media. Triyuwono, Iwan. 2000. Organisasi dan Akuntansi Syariah. Yogyakarta: LkiS.

Wasilah, Sri Nurhayati. 2011. Akuntansi Syariah, ed. 2, Jakarta : Salemba Empat. 